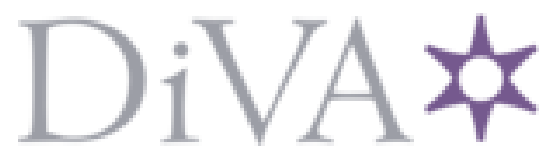

http://www.diva-portal.org

This is the published version of a paper published in International Journal of Organization Theory and Behavior.

Citation for the original published paper (version of record):

Alvinius, A., Wilde Larsson, B., Larsson, G. (2016)

Managing Boundaries in Integrated Care: A Qualitative Study of Collaboration between

Municipalities and County Councils in Sweden.

International Journal of Organization Theory and Behavior, 19(2): 139-165

Access to the published version may require subscription.

N.B. When citing this work, cite the original published paper.

Permanent link to this version:

http://urn.kb.se/resolve?urn=urn:nbn:se:fhs:diva-6314 
INTERNATIONAL JOURNAL OF ORGANIZATION THEORY AND BEHAVIOR, 19 (2), 139-165 SUMMER 2016

\section{MANAGING BOUNDARIES IN INTEGRATED CARE: A QUALITATIVE STUDY OF COLLABORATION BETWEEN MUNICIPALITIES AND COUNTY COUNCILS IN SWEDEN}

Aida Alvinius, Bodil Wilde Larsson, and Gerry Larsson*

ABSTRACT. Swedish healthcare has undergone continuous development over several decades. Today, legal responsibility is shared on the local and regional levels, i.e. between municipalities and county councils. The purpose of the present study is to gain a deeper understanding of boundary spanning roles and strategies involved in municipal and county council collaboration. A grounded theory approach was used. Fifteen informants from several Swedish health care authorities were interviewed. A tension exists between preserving boundary strategies that stifle collaboration and boundary spanning strategies that facilitate it. The way boundary spanners manage their role is assumed to influence the centre of gravity for this tension and thus the combination of favourable boundary spanning strategies and favourable boundary spanning roles is one way of getting the current form of collaboration to work.

\section{INTRODUCTION}

In Sweden, as in many other countries, there has been an increasing differentiation of roles and responsibilities in health care

* Aida Alvinius, Ph.D., is a Researcher, Department of Security, Strategy and Leadership, Swedish Defence University. Her research interest is in organization, collaboration and leadership, sociology of disasters, and military sociology. Bodil Wilde Larsson, Ph.D., is a registered nurse and Professor of Nursing at Karlstad University, Sweden, also adjunct professor at Hedmark University College, Norway. Her research interest is in quality of care, patient satisfaction, patient safety and quality of life. Gerry Larsson, Ph.D., is a Licensed Psychologist and Professor, Swedish Defence University; and a Professor, Hedmark University College, Norway. His research interest is in leadership, stress, patient satisfaction and quality of care.

Copyright $\odot 2016$ by Pracademics Press 
and social welfare contexts. Although the organization of Swedish health care goes back a century, laws on the division of responsibility between regional and local actors, i.e. county councils (health care) and municipalities (social welfare), only began to be implemented in the early 1990s (Ahgren \& Axelsson, 2011; see further details below).

In Swedish society, the elderly with multiple ailments, substance abusers and young people with psychological disorders are groups that have often fallen through the net when collaboration between county councils and municipalities has failed. This has occurred despite national goals for these actors to collaborate seamlessly in providing medical assessment, treatment and care to vulnerable groups (Ekstedt \& Ödegård, 2015; Kraus \& Lindholm, 2010; Lindholm, 2010; Storm, Siemsen, Laugaland, Dyrstad, \& Aase, 2014)

Existing research on collaboration between municipalities and county councils has mainly focused on favourable and unfavourable aspects from a business economic perspective (Lindholm, 2010, 2013). A few studies have focused on failings in collaboration regarding the elderly with multiple conditions (Andersson \& Karlberg, 2000; Falk \& Allebeck, 2002), while some have discussed vulnerable children (Germundsson, 2011) and the psychologically impaired (Strömberg Dominkovic, 2009). Two studies have looked at boundary setting and boundary spanning in health care (Currie, Finn \& Martin, 2007; Nylén, 2013). The issue has also been highlighted in a parliamentary initiated investigation (Milton, 2006a, 2006b).

Lindholm (2010, 2013) and Kraus and Lindholm (2010) have elucidated several reasons for why collaboration is not always seamless for the above mentioned groups. One reason is that both municipalities and county councils maintain strict budgets and do not see the long-term value of collaboration. Moreover, there is a fear that any transfer of resources and greater responsibilities will be costly. Other reasons include cultural differences between larger organizations, such as county councils, and the smaller municipalities, which have shorter chains of decision-making. Both types of organization operate on the basis of their own position and aims and often refer to their own internal working methods and regulations, duty of confidentiality and finances as reasons for failure to collaborate (Milton, 2006a). 
Collaboration between municipalities and county councils may be theoretically understood as structural and social inter-organizational interaction where the challenge exists in preserving, changing and also renegotiating boundaries which may be legal or financial (Nylén, 2007, 2013). Various strategies and boundary spanning roles are needed to manage these barriers as they can inhibit creative and developmental processes, something which may impact long-term on the health care of the most vulnerable (Nylén, 2013). Moreover, a number of researchers discuss the importance of managing boundaries due to their tendency to be reinforced, leading to negative consequences if collaborators such as municipalities and county councils view collaboration as a threat, rather than a tool (Currie, Finn, \& Martin, 2008; Nylén, 2013; Rodríguez, Langley, Béland, \& Denis, 2003; Turner, Pratkanis, \& Samuels, 2003).

Boundary-spanning roles and network strategies have been studied in a variety of organizational contexts (Granovetter, 1973, 1983) in both the public (Alvinius, Danielsson, \& Larsson, 2010; Kapucu, 2006; Kochan, 1975; Williams, 2002) and private sectors (Adams, 1976; Aldrich \& Herker, 1977; Dollinger, 1984; Fleming \& Waguespack, 2007; Tushman \& Scanlon, 1981) and from a cultural perspective in multi-national environments (Barner-Rasmussen, Ehrnrooth, Koveshnikov, \& Mäkelä, 2008). However, these studies may be of limited value when it comes to understanding the specific case of collaboration between the county council's health care system and the social welfare system of the municipalities.

However, one difficulty in relying on existing research is that the organizational structures for health care and social welfare differ widely from country to country. Publicly funded health care may be given on a state, regional, municipal or partially municipal level. Fully or partly private-funded care may exist in all kinds of forms, from small staff-owned cooperatives to large, multinational companies. Nevertheless, one common factor in the majority of the studied scenarios is that boundary spanning generally facilitates communication, resource- and knowledge-sharing and the management of social relations between hierarchical levels within organizations, as well as horizontally, between different organizations (for overviews, see Alvinius, 2013; Williams, 2002). Moreover, a commonly reported research finding is that successful boundary spanners facilitate the management of different types of uncertainties 
and risks associated with organizations and their collaboration, particularly in the public sector (Adams, 1976; Aldrich \& Herker, 1977; Johansson, 2009).

Looking at inter-organizational boundary spanning more in detail, a number of critical enablers and barriers have been identified in public administration. These include aspects such as formal structures, budgets, organizational commonality and complexity, power and politics, leadership and culture (O'Flynn, Blackman, \& Halligan, 2013).

Research is lacking, however, in regard to boundary-spanning roles and strategies in the collaboration between the two major actors in the health care and social welfare sectors, namely municipalities and county councils, which have a legal requirement to liaise in connection with the most vulnerable patient groups. Braithwaite (2010) and Meier (2015) point to the need for more research because of increasing pressure from the conditions under which collaboration must be practiced. In addition to this, there appears to be a lack of studies focusing on how's of boundary spanning in healthcare settings. Structural, organizational, economic concerns and professional roles have been more elucidated.

Therefore, the purpose of the present study was to gain a deeper understanding of boundary spanning roles and strategies involved in the collaboration between municipalities and county councils in relation to the provision of health care vulnerable patient groups: the elderly with multiple ailments, substance abusers and young people with psychological disorders.

\section{Characteristics of the Selected Context: A Swedish County Council and Swedish Municipality}

During the 1960s Sweden created an integrated system of health care on the regional level of the society. The responsibilities for primary health care and psychiatric care were decentralised from the national government to the county councils. (Ahgren \& Axelsson, 2011). In 1967, the county councils were responsible for all the different branches of health care including the general hospitals. They were also quite independent of the national government, since most of their activities were financed through county taxes. In the beginning of the 1990s, the responsibility for care of the elderly, care of the functionally 
disabled and long-term psychiatric care was transferred from the county councils to the municipalities. This was a national reform in order to improve the integration and collaboration between the health services of the county councils and the social services of the municipalities. In last two decades, the organizational picture has been additionally diversified due to an increasing number of private providers, mainly in primary health care and care of the elderly. These providers have been contracted through competitive procurement and financed by the county councils and the municipalities (Ahgren \& Axelsson, 2011).

The county council in this study oversees a population of approximately 300,000 . A politically governed organization, the council administers health and dental care and has just over 7,000 employees. There are three hospitals, approximately 30 local medical centres and 40 dental practices under its wing. Political control of the county council is exerted by the county council assembly, county council executive committee and auditors. The selected municipality is of average size for Sweden, with 90,000 inhabitants and is part of the studied county council. Also politically governed by a local assembly, the municipality is organised into a number of administrative boards which together employ approximately 7,500 people. The boards which primarily collaborate with the county council are the labour market and social services department, the Care of the elderly and the disabled department and the Childcare and Education Committee.

\section{METHODS}

The methodological approach was qualitative, informants from the chosen county council and municipality were interviewed. Data were analysed in accordance with the grounded theory method (Glaser, 2007, 2011, 2015; Glaser \& Strauss, 1967) and the result was a suggested theoretical model of boundary management in collaboration. Details are presented in the following.

\section{Informants}

In accordance with the guidelines for generating theory on an empirical basis (Grounded Theory) as developed by Glaser and Strauss (1967), the selection of informants was carried out with the aim of gathering the greatest possible variety of experiences. The informants were selected on the basis of their experience of collaboration between 
municipalities and county councils. A total of 15 people were interviewed (see Table 1).

The interviewees from the county council included a politician from the county council assembly, a medical division director, the director of an elderly care home and the director of local medical centres in a particular part of the town. Registered nurses and paramedics were also included in the study group. From the municipality, interviewees included political representatives of the Labor Market and social

TABLE 1

Overview of Informants

(Total Number of Informants $=15$ )

\begin{tabular}{|c|c|c|}
\hline County council & Municipality & Other \\
\hline $\begin{array}{l}\text { 1) County council } \\
\text { board with } \\
\text { overarching } \\
\text { responsibility for } \\
\text { collaboration } \\
\text { 2) One section } \\
\text { director and } \\
\text { Chief doctor at a } \\
\text { residence for } \\
\text { the elderly } \\
\text { 3) Head of East } \\
\text { NN health } \\
\text { centres, doctor } \\
\text { 4) Experienced } \\
\text { ambulance } \\
\text { driver } \\
\text { 5) Registered } \\
\text { nurse working at } \\
\text { a residence for } \\
\text { the elderly } \\
\text { 6) Registered } \\
\text { nurse } \\
\text { (previously head } \\
\text { of a clinic) }\end{array}$ & $\begin{array}{l}\text { 7) Chairman of the Labour } \\
\text { Market and social } \\
\text { serviced committee with } \\
\text { experience of } \\
\text { collaboration in relation } \\
\text { to social services issues } \\
\text { 8) Chairman of the Care of } \\
\text { the elderly and } \\
\text { the disabled committee } \\
\text { with experience of } \\
\text { collaboration in relation } \\
\text { to care of the elderly } \\
\text { 9) Care planning team, } \\
\text { representatives and } \\
\text { nurse } \\
\text { 10)District nurse from the } \\
\text { care home resource } \\
\text { centre } \\
\text { 11)Administrative head of } \\
\text { Care of the elderly and } \\
\text { the disabled department } \\
\text { 12)District nurse with } \\
\text { experience of both the } \\
\text { municipality and county } \\
\text { council }\end{array}$ & $\begin{array}{l}\text { 13) Researchers } \\
\text { and experts on } \\
\text { collaboration } \\
\text { between } \\
\text { municipality and } \\
\text { county council, } \\
\text { Department of } \\
\text { business studies, } \\
\text { Uppsala University } \\
\text { 14) Representative } \\
\text { of Region } \\
\text { Assembly, heading } \\
\text { 'New } \\
\text { Perspectives', a } \\
\text { vision for better } \\
\text { collaboration } \\
\text { between } \\
\text { municipalities and } \\
\text { county councils }\end{array}$ \\
\hline$N=7$ & $\mathrm{~N}=6$ & $N=2$ \\
\hline
\end{tabular}


service committee, Chairman and Administrative Head of the Care of the elderly and the disabled committee, representatives from a health care planning team and a care home, as well as district nurses and nurses with long experience of collaborating with the county council.

Other informants were a researcher who had especially studied the collaboration between municipalities and county councils, and a representative of the Region Assembly whose particular task was to supervise collaboration agreements between municipalities and the county council.

\section{Data Collection}

The interviews conducted for this study adhere to an interview guide consisting of open-ended questions, followed up with individually tailored questions such as "tell me more", "in what way", "can you give me an example", etc. The themes chosen were as follows:

- Background questions including own experience of collaboration between municipality and county council;

- Favourable aspects of collaboration between municipality and county council;

- Unfavourable aspects of collaboration between municipality and county council;

- Experience of tensions;

- Information and communication in collaborations; and

- Suggested improvements for increased collaboration

The interviews were conducted in the period February - May 2014. One interview took place in the informant's home, one took place at the Swedish National Defence College, one interview was conducted by telephone, and the remainder at the informants' respective places of work. The interviews, each lasting between 45-120 minutes, were conducted by the main author and two assistant interviewers (see acknowledgments). Of the 15 interviews, eight were recorded and transcribed in full, and the rest were documented by hand. The reason for not recording all interviews was that some informants felt uncomfortable with being recorded on tape. As two or sometimes three 
people were conducting the interviews, there was time for one to make notes while the others concentrated on the questions.

\section{Data Analysis and Presentation}

All of the interviews were analysed in accordance with grounded theory application (Glaser \& Strauss, 1967). The first step in this analysis consisted of what is known as open coding, which involves identifying units of meaning or codes in each individual interview. These could, for example, include special lines of thought, feelings or actions related to the interview's sphere of enquiry. An example of a quote coded as "Example of successful collaboration strategy" is given below:

For children and young people [with psychological disorders] we have devised a routine for collaboration - how to manage a child who is to be placed in a foster home. This is something the municipality and county council have agreed on. We have agreed what to do and the exact procedure for the somatic investigation; the paediatricians in our county have agreed to do this on behalf of the county council. The paediatricians, specialists have chosen to do so. Dental health has said yes...it's loud and clear. If we get it to work remains to be seen but it's a huge example of something that was really complicated two or three years ago but we now have guidelines. It's fantastic being able to get the paediatricians out to these foster kids.

Step two in the analysis consisted of evaluating and categorising the codes according to similar content. From the above example and other similar types of codes, the category "Structural boundary spanning strategies" was developed and in the third step sorted into the superior category "boundary spanning strategies." In the fourth step, this superior category was sorted into the over-arching category "Managing boundaries in collaboration" (so called core variable). The final step involved a comparison between the over-arching category, the superior categories, categories and the codes, generating a hypothetical model, which is presented in the Results section below. After analysing the first twelve interviews it was decided that new data did not contribute further substantive information and theoretical saturation had been achieved (Glaser \& Strauss, 1967). This was confirmed in three additional interviews. 


\section{RESULTS}

\section{Managing Boundaries in Collaboration}

Collaboration between municipality and county council regarding vulnerable patient groups is a continuous process in which various types of boundaries, boundary construction and de-construction must be managed, and for this reason we have named the model's overarching category 'Managing boundaries in collaboration'. The boundaries in question may be horizontal or vertical, within or between organizations, just as boundaries might stem from different areas of responsibility or between professions. In many cases, the boundaries may be of a legal or economic nature, but they may equally be about attitudes towards collaboration that both help or hinder activities. The process also decides what need there is for boundary spanning roles and what kind exist. Further, boundary spanning roles in themselves can be of help or hindrance in the collaboration process.

The main category, 'Managing boundaries in collaboration' consists of three sub-categories: Preserving boundary strategies, Boundary spanning strategies and Boundary spanner roles. The model postulates that a tension exists between preserving boundary strategies that stifle collaboration and boundary spanning strategies that facilitate it. The way boundary spanners manage their role is assumed to influence the centre of gravity for this tension and thus the combination of favourable boundary spanning strategies and favourable boundary spanning roles is one way of getting the current form of collaboration to work. The above categories are presented in more detail in the model below (Figure 1).

\section{Preserving Boundary Strategies}

Boundary-preserving strategies involve various ways of reinforcing one's territory and therefore hamper collaboration between two organizations. This can happen at all organizational levels and within both the municipality and the county council. Boundary preservation may be of a relational and structural nature. The borderline between these two strategies is sometimes blurred and both may also contain procedural aspects with no apparent intentions to prevent collaboration. This strategic part also includes structural aspects which are more of barriers to collaboration than conscious attempts to preserve boundaries. 
FIGURE 1

Model of Managing Boundaries in Collaboration between Municipalities and County Councils

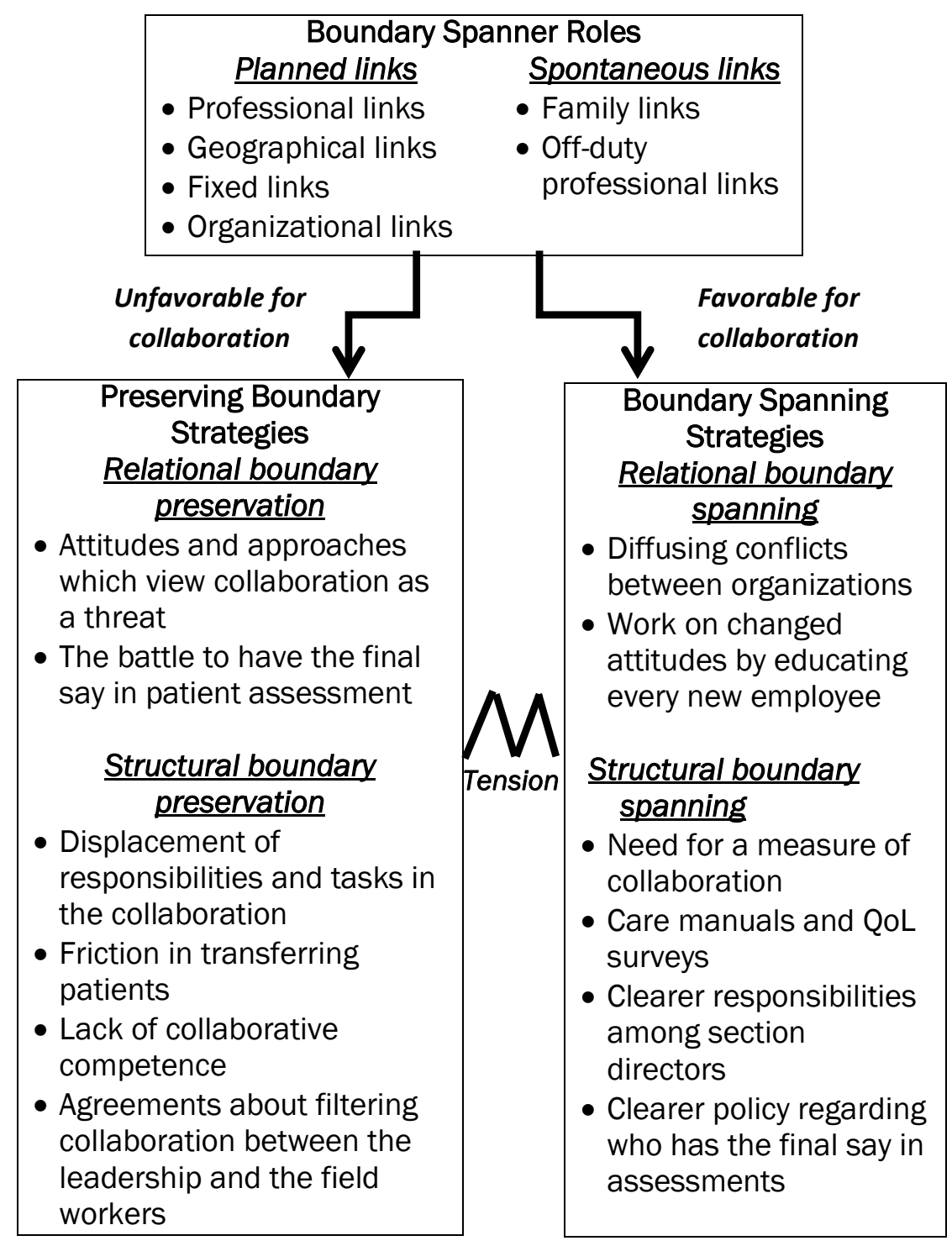


Relational boundary preservation is about (1) attitudes and approaches which view collaboration as a threat rather than an asset at all organizational levels, and here we could talk about a 'closed door' principle. Relational boundary preserving strategies may also concern (2) the battle to have the final say in a patient assessment, which reflects a hierarchical power issue in relations. Both of these aspects may be illustrated with a quote from a political representative of the municipality with long experience of collaboration between municipality and county council:

On one occasion involving a patient and the police, the emergency psychiatry unit wouldn't open up. This was common at the time. As a consequence, there were huge workenvironment problems for the social services staff because the patient could be a danger to himself and those around him, so the municipality staff assessed him to be extremely dangerous. /.../. The County council staff make a different assessment to the municipality staff, meaning the county council 'overrides' the assessments made by the municipality.

Structural boundary preservation relates to the following aspects: (1) displacement of responsibilities and tasks in the collaboration between organizations and between units within the same organization, (2) friction in transferring patients between municipality and county council and vice versa, as well as shortcomings in working methods that later lead to delays of different kinds and (3) lack of collaborative competence at higher levels, municipal staff's lack of healthcare and medical competence in connection with the needs of people with immigrant backgrounds and conversely, language difficulties of staff with immigrant backgrounds. Lastly, structural boundary preservation may concern (4) agreements about filtering collaboration between the leadership and the field workers because the latter are more frequently replaced. These structural factors hamper collaboration between municipality and county council.

Displacement of responsibility, territorial marking and hierarchical thinking among doctors were all mentioned in the interviews. One informant from the municipality said this:

Our hierarchy is a parallel one. There's a leadership structure involving a strong hierarchy among the doctors. Yes, this is the dilemma at the county council. This double standard is still around...that politically you want to write but you always have 
the doctors with their right to veto. These parallel systems are difficult to change and make breakthroughs in. /.../. This is foreign to us in the municipality - it's a little easier to manage and clearer what's political and what is the administration's responsibility. If you control something as a boss in our organization, it isn't questioned in that way.

One informant felt that the reforms and legislation that led to shared responsibility between county council and municipality had in fact failed. The person in question, representing the municipality, said this:

Mental health problems and substance abuse go together. They think it's about abuse, the municipality say it's mental health. Does the patient have a psychological disorder or is he a substance abuser? What came first - the chicken or the egg? Social services can never back off, BUT the staff aren't qualified to handle mental health problems. 'Bengt' doesn't fall through the net, he ends up in municipal care and goes into a home for abusers. But substance abuse should be an issue for the county council because they have the skills to manage it.

Another aspect is displacement of responsibility when one organization shrugs it off onto another party. This was expressed as follows by an informant from the municipality:

I think it's a question of resources on the part of the county council. Because you always think someone else is going to come up with the goods - it's always like that (laughs). And I think the county council is so large that each local health centre makes its own decisions in some way. It's difficult to make headway with your ideas and get people to act on them.

Friction in transfer concerns procedural aspects, delays caused by poor working methods. This has been highlighted by both the county council and municipality. Discussions with experts who have researched this field and comments in the interviews typically mention friction in transfer and movement of patients from one place to another. For example, the hospital might not dispatch correct prescriptions - they might be incomplete, out of date and most frustratingly, pose a serious threat to patient safety if incorrect medication is administered. Some informants have mentioned further repercussions of this - that such carelessness means more work for the nurses, the prescriptions are not at the pharmacy; the pharmacy 
leaves it to the nurses to check the validity of the prescriptions etc. Another obstacle is different systems handling the same information, as highlighted in the following quote from an informant representing the county council:

MEDICS is the information system linked to the computer network where it has to be done. It might be that the nurse gets it but it hasn't gone through to the health centre and then it gets stuck there because the doctor isn't really in the loop then. So sometimes it might feel more difficult to get primary care and in-patient care together than it is to get the municipality and these parties together.

Delays within organizations also occur, as described below by an informant from the municipality:

We have problems with pick-up services - that they don't come at the time we arranged. So the care staff are standing around waiting and they don't come until some hours later. Interviewer: Who is responsible for pick-up services? Respondent: It's within the municipality but it's not the Care of the elderly and the disabled department, it's Building Committee and that's another organization where they're all buying in services and trying to more effectively manage things.

Skills shortage involves a number of aspects. Some informants described their concern about the low level of competence exhibited by home care staff. Home care is the closest form of care for the patient and there are many shortcomings in the basic care provided. Areas in which a patient may need help with include getting out of bed, getting washed and dressed, taking medicine, eating, drinking, etc. One informant said of this: "Many of them don't even know how to make porridge or make the bed properly." Another mentioned language difficulty to illustrate lack of competence: "Lots of immigrants work in home care and they are doing great in all kinds of ways but have major difficulties with the language. It's difficult when they call and want advice about the patient." Another informant saw the need for in-depth education of district nurses, primarily in regard to wound care, palliative care and diabetes. If their knowledge and skills were greater they would have the confidence to do more in the patient's home rather than sending him or her to the hospital. 
Other types of ignorance that preserve structure involve agreements that filter between organizational levels leading to collaboration decisions and policies that lack continuity among field staff. This was highlighted by one of the county council informants we interviewed:

On the other hand, there are more examples - I think it's more to do with ignorance regarding each other's field of operations. You might not know but believe that as a doctor you can prescribe short-term care, but that's not really how it works. It's ignorance on the part of individuals. Because when you talk to the management we're all in agreement, but people change jobs a lot so it isn't that strange.

Finally, it's about people who are closest to the ground...l've written 6 metre stacks of agreements...but when you think that has to go to the final frontier, we can make agreements as long as we like at this level - it doesn't filter down.

\section{Boundary Spanning Strategies}

Boundary spanning strategies are about favourable aspects of collaboration and can be separated into relational and structural boundary spanning strategies. All the interviewees were aware of these strategies and approaches and claimed they made collaboration more effective. Once again it should be noted that borderline between the two strategies is sometimes unclear (see section on Boundary Preserving Strategies above).

Relational boundary spanning primarily concerns human relations as a way of bridging boundaries. One aspect (1) regards diffusing conflicts between organizations. To do this, one county council nurse suggested the collaborators made study visits on each other (auscultation), shared common training sessions and conferences and established personal contacts. According to the nurse, this would considerably promote collaboration. Another aspect (2) is working with changed attitudes by educating every new employee in the organization. An informant from a Region Assembly phrased it like this:

It's never-ending - if there's one person who can't handle issues in collaboration then we have work to do. We have more than 7,000 employees in the county council. There are many thousands in the municipalities - it's about each link being 
able to work. Somehow, to reach the goal it will take time. /.../. I mean it's a never-ending task.

Structural boundary spanning concerns organizational aspects where various tools, division of responsibilities and polices for collaboration agreements were mentioned in the interviews. A common feature of these aspects is partly that they are not tied to individuals and partly that they are an expression of need for structure in both organizations. The categories emerging from the analysis relate to (1) measure of collaboration, (2) care manuals and quality of life surveys, (3) clearer responsibility among section directors and (4) clearer policy regarding who has the final say in assessments. The following quote relates to the need for a measure of collaboration with the aim of understanding what will be gained through cooperation. The first is from an expert on collaboration between municipality and county councils:

On an intellectual level, lots of people understand that we have to find a means of steering towards collaboration. If we could only find a measure to show that collaboration brings great benefits - we would win a lot of ground like that.

Working methods like the introduction of a care manual and quality of life surveys would partly be based on a patient perspective to ensure sufficient information provision, for example, in regard to distribution of medicines. A municipality informant said this:

A number of times I have felt a powerful and challenging resistance from county council staff towards municipality staff. In my own field, a personal 'care manual' for patients was introduced. Each patient 'owned' their own book and decided what was to be written in it. The book was seen as a source of current care information - changes in the patient's condition, test results, wishes /.../. The care recipient felt more part of things. We didn't see confidentiality as a problem here. Also, one advantage was that relatives had access to the book. It could be viewed as a journal for them to share.

We also did quality of life surveys to find out what the seriously ill elderly wanted. This was important as those wishes were very personal and did not apply to everyone. They might have 
wanted to sit by the window and watch the birds or to decide what radio channel to listen to.

Structural boundary spanning is also described as clearer positions with section directors taking the lead and more transparent responsibility. The following quote comes from another municipality informant:

You often find yourself in a system where bosses control their areas and it seems difficult to get an overarching sense of "we have to do this now" - those common efforts, I think. It can be difficult in both primary and in-patient care - even if we think it's got better recently. Things are clearer about the section bosses at the county council, they have more transparent responsibilities. It's easier to conduct a dialogue than how it was before.

The policy regarding clearer agreements regarding the final say in patient care was also raised. The following quote mentions existing structure on how to conduct an evaluation, although earlier results demonstrated the contrary. An excerpt from an interview with an informant representing the municipality:

We have come to the conclusion that when something happens and there's ambulance staff and a district nurse present, it's the district nurse who has the final say. And whoever thinks that person should go to hospital, that's what will happen.

\section{Boundary Spanner Roles}

Boundary spanning roles relate to individuals or groups of individuals with specific competence, knowledge, skills and approach that can act both to oil the wheels of collaboration and to act as a brake on it. We have separated these into Planned and Spontaneous Links concepts derived from Alvinius, Danielsson, and Larsson. (2010). A Planned Link is related to an individual's organizational role and is most often approved and accepted by superiors. Planned Links refer to individuals with collaboration tasks within their responsibility and mandate. In contrast, Spontaneous Links appear to arise when required by the situation. This could happen when areas of responsibility, authority, competences, experiences and resources fail. Spontaneous Links often emerge in the field and enjoy the immediate trust of people close by, for example Planned Links. 
Planned links in this article, examples of these include: (a) professional links, (b) geographical links, (c) fixed links and (d) organizational links.

\section{Professional Links}

These derive from different professional groups involved in the collaboration between county council and municipality. Professional links can be both positive and negative. The examples below come from informants from both the municipality and county council. One need for this type of role is clear from our analysis:

The few examples that have succeeded - in these particular cases seem to be dependent on the individual - having a position in the organization that is naturally inclined towards collaboration.' How is such a position formalised? A competent doctor with legitimacy and approval usually works well.

The medical secretaries hold onto the reports for far too long because the doctors have forgotten to sign them. It causes huge delays in patient care.

If it works or not depends a lot on the competence of the doctor in charge. It's very important they have knowledge and experience of geriatric care.

\section{Geographical Links}

These refer to the mobile team of doctors who can easily transport themselves to patients' homes. Being a geographical link may also mean side-stepping the local health centre because it is quicker to fetch medicines from the central hospital. This short-circuits the organization but solves the task more quickly as illustrated by informants from the municipality.

I can tell you about something we discussed among ourselves and it's about getting doctors out to people's homes when necessary. It's partly to avoid an unnecessary trip to the hospital and sometimes also...even if you always try to think we have decision-makers up to nurse level, there's still always something missing. You can't always get hold of the doctor, to get someone to actually go visit the home and check. This thing about doctors and home visits. I feel it's something for those of 
us in the municipality - it would help both sides if we got that support.

When a medical report is missing we directly arrange for one at the hospital instead of going through the local health centre.

\section{Fixed Links}

These are about continuous contact with doctors to facilitate continuity of care and more cohesive patient records. This has been particularly successful in senior residences when the person in charge is, in fact, a doctor. Two illustrations, the first representing the municipality and the second the county council:

At our special care homes the municipality-county council collaboration works well. The doctors in charge make regular visits there.

Communication between the municipality and county council is at its very best with respect to the elderly who have an established diagnosis and thereby established contact with a doctor. Nevertheless, problems may arise when the local health centre has to rely on locums, meaning it cannot maintain continuity.

\section{Organizational Links}

These relate to the organizations themselves as links. An emergency unit, for example, is seen as a gateway to 'all-inclusive' service at all hours. In other cases, an administrative body can be seen as a link between two collaborators. This may be perceived as both positive and negative and involve several collaborative parties. A Region Assembly informant:

It's something about the attitudes. Emergency is emergency. Why do people go to emergency? I conducted a small Gallup poll - as many as $80 \%$ wanted to go there for things like if their child was sick. When asked why - it's always open; you get allinclusive service, the lab, X-ray, the whole lot. You don't get that at the local health centre. There's an attitude towards the Emergency unit that is...well....an answer to everything. 


\section{Spontaneous Links}

These are identified as (a) family links and (b) off-duty professional links. We should add to the definition of spontaneous links here that family, while not employed, can contribute to continuity in patient assessment whereas locums employed by the county council do not provide continuity. The interviewees saw both the advantages and disadvantages of this.

(a) Family links: relatives who make demands and give their assessment of the patient. The following quotes comes from the municipality and county council respectively:

When the doctors fail to do their job properly, a lot of responsibility falls on the family.

One change in recent years is that family members increasingly get involved in the healthcare of the elderly - which is both good and bad. Relatives make demands that we sometimes find challenging. They take issue with the nurse in charge and often demand that the elderly person is sent to Emergency (just to be sure).

(b) Off-duty professional links are nurses who work in their free time to make things easier for a patient. Employed locums recruited to the countryside where no other doctors want to work are also a type of professional link. A county council informant:

The municipality nurses running to the hospital to fetch medicines or going to the pharmacy to pick up patients' prescriptions, which they do in their free time because they're 'nice' - it's completely unreasonable!

\section{DISCUSSION}

The aim of this study was to gain a deeper understanding of boundary spanning roles and strategies in the collaboration between municipality and county council in regard to the provision of health care to the following patient groups: the elderly with multiple conditions, substance abusers, and young people with psychiatric difficulties. Three key "how-oriented" concepts were identified regarding this collaboration: the management of boundary spanning roles, boundary preservation and boundary spanning strategies, which are in constant 
interplay. By using the constant comparative method (Glaser and Strauss, 1967), we identified relational and structural boundary preservation as well as boundary spanning actions. Boundary spanners could also be divided into two different types, namely, planned and spontaneous.

Possibly, the most important theoretical result of the study is the proposed tension between preserving boundary strategies that impede collaboration and boundary spanning strategies that facilitate collaboration, and the importance of how boundary spanners manage their roles in determining where the focus of this tension lies. The combination of favourable management of the boundary spanning and networking strategies and favourable management of the boundary spanning roles is a way of getting the current form of collaboration to work. This healthcare sector finding may be regarded as a theoretical contribution to the general field of inter-organizational boundary spanning as summarized by Braitwaite (2010), Granovetter (1973, 1983) and O'Flynn, Blackman, \& Halligan (2013). The main suggested practical implication of the study is that the suggested model may be valuable when developing integrated care and in educational settings. In addition to this, suggestions provided by the informants deserve further attention. These include a sustainable system for educating new employees on the necessity of collaboration, further use of care manuals and quality of life surveys, and attempts to find valid and reliable measures of the quality of collaboration between municipalities and county councils.

As mentioned in the introduction, the research on collaboration between municipalities and the county councils is limited and has mainly focused on problems from an economic perspective. Compared to this research, our contribution differs in that it has functionalistic import in focusing not only on unfavourable factors but also highlighting favourable ones from a behavioural science perspective. This is in line with Schultz's theory (1990), which advocates the external study of organizations from a functionalistic starting point.

More specifically, the behavioural science approach pointed to details in the interpersonal relationship area not as clearly mentioned in previous research on boundary spanning in the health care setting. One such aspect is the importance of attitudes. The risk of perceiving interorganizational collaboration as a threat was clearly observed, as was the need to continuously conduct personnel education on these 
matters. Due to a high amount of personnel turnover at the lowest organizational level, with many having an immigrant background and limited skill in the Swedish language, this need for education was accentuated.

Another relationship-related aspect not observed in a similar way previously, was the boundary preserving strategy we labelled "the battle to have the final say in a patient assessment". This code obviously also contains a strong element of power structure. Our interpretation is that it illustrates the central role doctors have as links in boundary spanning. By virtue of their professional status, doctors can influence boundary spanning to produce both positive and negative consequences. There are a number of possible reasons for this. One is their own mind set in relation to collaboration. If the doctors are engaged in collaboration, the latter is made significantly easier and vice versa (cf. Abramson and Mizrahi, 1996). Clarity of remit and responsibility were, for instance, raised as being favourable to boundary spanning. This is in line with results reported regarding care and social welfare for children (Widmark, Sandahl, Piuva, \& Bergman, 2011).

Another potential reason is the formal rules that control a doctor's area of responsibility. In Sweden, for example, doctors are not employed by the municipality but by the county council. A third reason is cultural tradition, which means doctors in their professional capacity acquire greater powers and legitimacy to decide the direction of boundary spanning. We may understand the latter in terms of shadow structures (McGuire, 2002), which in this case mean the formal decision-making powers of other professional groups may be overridden by the medical profession's informal, expert-related powers.

Regarding methodological considerations, it should be mentioned that this investigation does not permit generalizations. However, this was not the goal of this qualitative study. In the general terms of Glaser and Strauss, (1967), "Partial testing of theory, when necessary, is left to more rigorous approaches (sometimes qualitative but usually quantitative). These come later in the scientific enterprise" (p. 103). It should be emphasized that the concepts derived from the data may be of a sensitizing, rather than a definitive character, to use Blumer's (1954) words. Another study weakness is that interview responses not only reflect the informant's thoughts on how things really are, but partly 
also how they would like them to be. Given this kind of conversations about open-ended themes this may be unavoidable. However, we may have contributed to this mixture of belifs and commitments by mentioning the last question in the interview guide: suggested improvements for increased collaboration. This was emphasized in the present case regarding relational bounding preserving and structurally boundary preserving as well as relational boundary spanning and structural boundary spanning.

It should also be noted that the study relies on self-reported data only. These may be inaccurate, and a broader range of data would have been desirable. Although the interview data is based on a limited number of informants, this form of information is important as it contributes to our understanding of the informants' work duties and the relationship between problems that may arise with establishing collaboration between municipalities and county councils in Sweden.

Given the abovementioned limitations, the suggested model should be viewed as preliminary, and further studies are suggested to evaluate the generalizability of the study. For example, the relevance and the suggested content of the superior categories Preserving boundary strategies, Boundary spanning strategies and Boundary spanner roles could be further investigated in other contexts such as interactions between public, partly private and fully private financed care and welfare.

\section{ACKNOWLEDGEMENT}

We appreciate Heléne Thorvaldstotter Dehring's and Malin Berglund's help with the data collection.

\section{REFERENCES}

Abramson, J. S., \& Mizrahi, T. (1996). "When Social Workers and Physicians Collaborate: Positive and Negative Interdisciplinary Experiences." Social Work, 41(3): 270-281.

Adams, S. J. (1976). "The Structure and Dynamics of Behavior in Organizational Boundary Roles." In M.D. Dunnette, (Ed.), Handbook of Industrial and Organizational Psychology (pp. 1175-1199). Chicago, IL: Rand McNally College Publishing Company. 
Ahgren, B., \& Axelsson, R. (2011). "A Decade of Integration and Collaboration: The Development of Integrated Health Care in Sweden 2000-2010." International Journal of Integrated Care, 11(5): 1-8.

Aldrich, H., \& Herker, D. (1977). "Boundary-Spanning Roles and Organization Structure." Academy of Management Review, 2(2): 217-230.

Alvinius, A., Danielsson, E., \& Larsson, G. (2010). "The Inadequacy of an Ordinary Organisation: Organisational Adaptation to Crisis Through Planned and Spontaneous Links." International Journal of Organisational Behaviour, 15(1): 87-102.

Alvinius, A. (2013). Bridging Boundaries in the Borderland of Bureaucracies - Individual Impact on Organisational Adaption to Demanding Situations in Civil and Military Contexts. Unpublished Dissertation. Karlstad, Sweden: Faculty of Arts and Education, Karlstad University Studies.

Andersson, G., \& Karlberg, I. (2000, November). “Integrated Care for The Elderly: The Background and Effects of the Reform of Swedish Care of the Elderly." International Journal of Integrated Care, 1: 110.

Barner-Rasmussen, W., Ehrnrooth, M., Koveshnikov, A., \& Mäkelä, K. (2014). "Cultural and language skills as resources for boundary spanning within the MNC." Journal of International Business Studies. 45(7): 886-905.

Blumer, H. (1954). "What Is Wrong with Social Theory?" American Sociological Review, 19(1): 3-10.

Braithwaite, J. (2010). "Between-group Behaviour in Health Care: Gaps, Edges, Boundaries, Disconnections, Weak Ties, Spaces and Holes: A Systematic Review." BMC Health Services Research, 10(1): 330-340.

Currie, G., Finn, R., \& Martin, G. (2007). "Spanning Boundaries in Pursuit of Effective Knowledge Sharing within Networks in the NHS. Journal of Health Organization and Management, 21(4/5): 406417. 
Currie, G., Finn, R. \& Martin, G. (2008). "Accounting for the 'Dark Side' of New Organizational Forms: The Case of Healthcare Professionals." Human Relations, 61(4): 539-564.

Dollinger, M. J. (1984). "Environmental Boundary Spanning and Information Processing Effects on Organizational Performance." Academy of Management Journal, 27: 351-368.

Ekstedt, M. \& Ödegård, S. (2015). Exploring Gaps in Cancer Care Using a Systems Safety Perspective. Cognition, Technology \& Work, 17(1): 5-13.

Falk, K., \& Allebeck, P. (2002). "Implementing Assertive Community Care for Patients with Schizophrenia." Scandinavian Journal of Caring Sciences, 16(3): 280-286.

Fleming, L., \& Waguespack, D. M. (2007). "Brokerage, Boundary Spanning, and Leadership in Open Innovation Communities." Organization Science, 18(2): 165-180.

Germundsson, P. (2011). Lärare, Socialsekreterare Och Barn Som Far IIla: Om Sociala Representationer Och Interprofessionell Samverkan. [Teachers, social workers and children at risk. On social representation and interprofessional collaboration]. Örebro, Sweden: Örebro University.

Glaser, B.G. (2007). "All Is Data." The Grounded Theory Review. An International Journal, 6(2): 1-22.

Glaser, B. G. (2011). Getting Out of the Data: Grounded Theory Conceptualization. Mill Valley, CA: Sociology Press.

Glaser, B. G. (2015). Choosing Grounded Theory: A GT Reader of Expert Advice. Mill Valley, CA: Sociology Press.

Glaser, B., \& Strauss, A. L. (1967). The Discovery of Grounded Theory: Strategies for Qualitative Research, Chicago, IL: Aldine.

Granovetter, M. S. (1973). "The Strength of Weak Ties." American Journal of Sociology, 78(6): 1360-1380.

Granovetter, M. (1983). "The Strength of Weak Ties: A Network Theory Revisited." Sociological Theory, 1(1): 201-233.

Johansson, R. (2009). “Gränsöverbryggarna och de Oorganiserade Frivilliga: Olycksplatsen som Mötesplats [The boundary bridgers and the unorganized volunteers: the scene of an accident as a 
meeting place]." In C. Roman, and L. Udehn (Eds.), Från Klass Till Organisation - En Resa Genom Det Sociala Landskapet (pp. 190208). Malmö, Sweden: Liber förlag.

Kapucu, N. (2006). "Interagency Communication Networks during Emergencies: Boundary Spanners in Multiagency Coordination." American Review of Public Administration, 36(2): 207-225.

Kochan, T. A. (1975). "Determinants of the Power of Boundary Spanning Units in an Interorganizational Bargaining Relation." Administrative Science Quarterly, 20(3): 434-452.

Kraus, K. \& C. Lindholm, (2010). "Accounting in Inter-Organisational Relationships within the Public Sector." In H. Håkansson, K. Kraus, and J. Lind, (Eds.), Accounting in Networks (p.p. 113-148), New York: Routledge.

Lindholm, C. (2010). Styrning mot Samverkan och Styrning av Samverkan: En Studie av Närvårdsprojektet i Uppsala län. [Managing towards collaboration and management of collaboration. A study of Community Care project in Uppsala county council]. Regionförbundet, Sweden: Uppsala län.

Lindholm, C. (2013). "Styrning och Ansvar i Utvärdering av Samverkanseffektivitet" [Management and responsibility in the evaluation of the collaboration efficiency]. In R. Axelsson \& Bihari S. Axelsson (Eds.), Om Samverkan - För Utveckling av Hälsa och Välfärd, [On collaboration - for the development of health and welfare] (pp. 345-361). Lund, Sweden: Studentlitteratur.

Meier, N. (2015). "Collaboration in Healthcare Through Boundary Work and Boundary Objects." Qualitative Sociology Review, 11(3): 60-82.

McGuire, G. M. (2002). "Gender, Race, and the Shadow Structure a Study of Informal Networks and Inequality in a Work Organization", Gender \& Society, 16(3): 303-322.

Milton, A. (2006a). Vård och stöd till psykiskt störda lagöverträdare. [Care and support for mentally disordered offenders]. SOU 2006: 91, Official Reports of the Swedish Government, Sweden, Stockholm: Ministry of Health and Social Affairs.

Milton, A. (2006b). Ambition och Ansvar-Nationell Strategi för Utveckling av Samhällets Insatser Till Personer Med Psykiska Sjukdomar Och Funktionshinder. [Ambition and Responsibility. 
[National strategy for development of community initiatives for persons with mental illnesses and disabilities]. (SOU 2006:100). Sweden, Stockholm: Ministry of Health and Social Affairs.

Nylén, U. (2007). "Inter-agency Collaboration in Human Services: Impact of Formalization and Intensity on Effectiveness." Public Administration, 85(1): 143-166.

Nylén, U. (2013). "Boundary Preservation or Modification: The Challenge of Collaboration in Health Care." Scandinavian Journal of Public Administration, 16(2): 115-142.

O'Flynn, J., Blackman, D., \& Halligan, J. (2013). Crossing Boundaries in Public Management and Policy: The International Experience. New York: Routledge.

Rodríguez, C., Langley, A., Béland, F. \& Denis, J-L. (2003) “Managing across Boundaries in Health Care: The Forces for Change and Inertia." In N. Paulsen, \& T. Hernes (Eds.), Managing Boundaries in Organizations: Multiple Perspectives (pp. 147-168). New York: Palgrave Macmillan.

Schultz, M. (1990). Kultur i Organisationer. [Culture in Organizations]. Copenhagen, Denmark: Handelshøjskolens Forlag.

Storm, M., Siemsen, I. M. D., Laugaland, K. A., Dyrstad, D. N., \& Aase, K. (2014) "Quality in Transitional Care of the Elderly: Key Challenges and Relevant Improvement Measures." International journal of integrated care, 14(2): 1-15.

Strömberg Dominkovic, N. S. (2009). Samverkan Kring Vuxna Personer Med Psykisk Funktionsnedsättning Och Psykisk Sjukdom. [Collaboration about Adults with Mental Disabilities and Mental IIIness]. Stockholm, Sweden: Kommunförbundet i Stockholms län.

Turner, M.E., Pratkanis, A.R., \& Samuels, T. (2003). "Identity Metamorphosis and Groupthink Prevention." In S.A. Haslam, D. van Knippenberg, M.J. Platow, and N. Ellemers, (Eds.), Social Identity at Work - Developing Theory for Organizational Practice (pp. 117138). New York: Psychology Press.

Tushman, M. L. \& Scanlan, T.J. (1981). "Boundary-Spanning Individuals: Their Role in Information Transfer and their Antecedents." Academy of Management Journal, 24(2): 289-305. 
Widmark, C., Sandahl, C., Piuva, K., \& Bergman, D. (2011, September). "Barriers to Collaboration between Health Care, Social Services and Schools." International Journal of Integrated Care, 11: 1-9.

Williams, P. (2002). "The Competent Boundary Spanner." Public Administration, 80(1): 103-124. 